\title{
KONSEP DASAR BIMBINGAN KARIER MODERN DALAM PERSPEKTIF MANUSIA RELIGIUS
}

\section{Sugandi Miharja}

UIN Sunan Gunung Djati

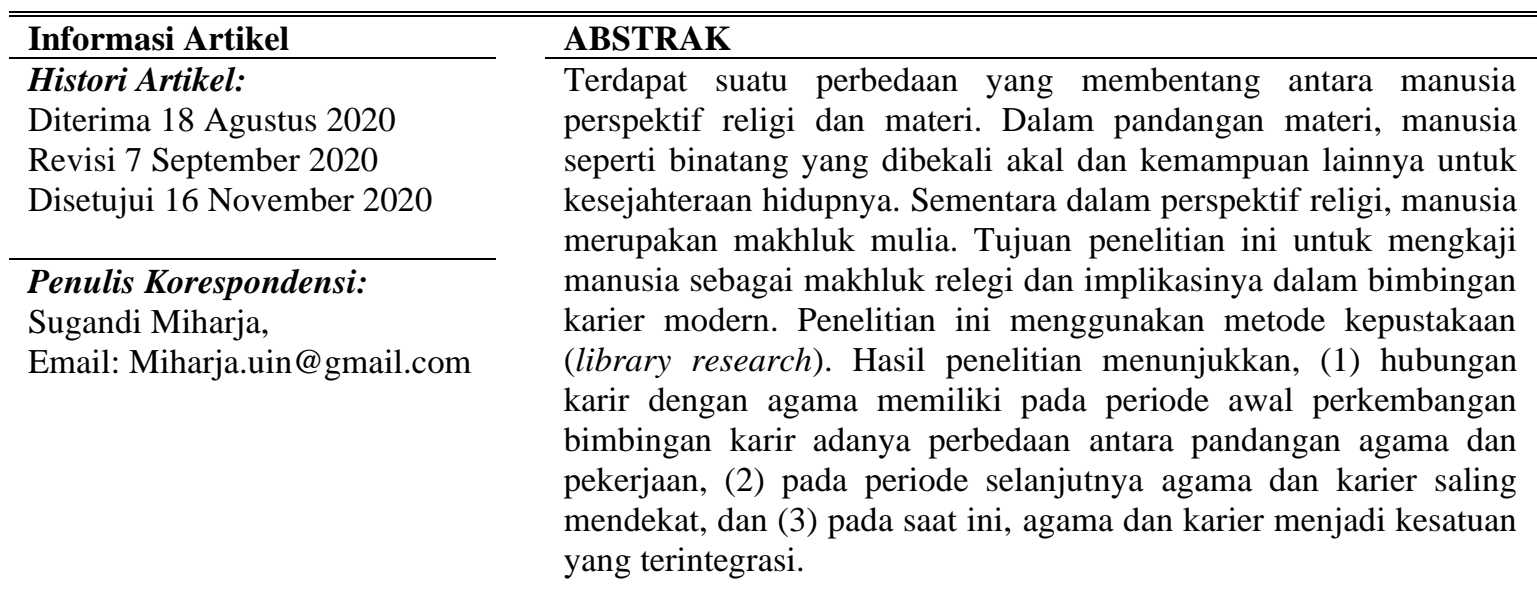

Kata kunci: Manusia; religius; konsep karier

\section{PENDAHULUAN}

Terdapat suatu perbedaan yang membentang antara manusia menurut religi dan materi. Secara materi manusia ibarat suatu makhluk binatang yang dibekali akal dan kemampuan lebih untuk kesejahteraan hidup secara ekonomi. Konsep manusia perspektif materi adalah dorongan untuk mengejar bendawi, seperti menghasilkan uang, mendapat upah yang tinggi, untung besar, memiliki barang-barang yang berharga, dan menikmati wisata ke tempat-tempat menyenangkan. Sikap kebendaan semata ini ibarat binatang pada umumnya, dimana insting untuk memenuhi tuntutan makan dan kesenangan menjadi satusatunya yang prioritas. Sikap demikian muncul karena pandangan ini lebih mementingkan pemenuhan materi.

Dalam pandangan sekuler, manusia dipandang sebagai spesies primata yang diberi otak cerdas. Pandangan awal tentang pribadi manusia dalam kategori sebagai makhluk 
biologis dan antropologis. Secara biologis manusia diklasifikasikan sebagai spesies primata dari golongan mamalia yang dilengkapi otak yang berkemampuan tinggi.

Dalam Antropologi, manusia dibedakan berdasarkan penggunaan bahasa, organisasi masyarakat, teknologi, serta komunitas yang saling mendukung (Maryam, 2017). Dalam pandangan ilmuan sekuler manusia setidaknya ada dalam enam identifikasi, antara lain (1) animal rational yang berarti hewan yang berpikir, (2) homo sapiens yang berarti manusia berbudi, (3) homo laquen yang berarti makhluk yang pandai menerjemahkan pikiran dan perasaan manusia dalam bentuk kata-kata, (4) homo faber, yaitu makhluk yang terampil dan pandai membuat alat-alat kebutuhannya, (5) zoon politicon, yaitu makhluk yang pandai bekerja sama, bergaul dengan orang lain dan mengorganisir diri untuk memenuhi kebutuhan hidupnya, (6) homo ekonomicus yaitu makhluk yang tunduk pada prinsipprinsip ekonomi.

Pada pandangan religi, manusia merupakan makhluk mulia yang melampau pemenuhan kebutuhan materi. Dorongan rasa dan karsa untuk kebanggaan hidup sesuai aturan dan aturan agama menjadi pendorong utama. Sikap empati, semangat menolong, dan menjadi solusi atas persoalan kehidupan sosial sebagai wujud tertinggi dalam hubungan antar manusia. Ia menjadi hangat dan energik dalam mengamalkan ajaran agama dan menjadi garda depan yang hubungan sosial antar manusia. Adapun pemenuhan kebutuhan materi dijadikan sebagai alat untuk mewujudkan aspek agama dan sosial. Materi adalah salah satu modal untuk mewujudkan kebaikan sebagai pengamal agama dan berkehidupan secara sosial.

Manusia merupakan makhluk paling sempurna yang diciptakan oleh Tuhan. Dalam diri manusia terdapat aspek rohani dan jasmani. Secara terperinci Al-Qur`an membagi tiga komponen dalam diri manusia, yakni basyar bahwa manusia adalah makhluk biologis; $A l$ Insan, manusia sebagai khalifah atau pemikul amanah; dan Al-Nas bahwa manusia adalah makhluk sosial (Afrida, 2018). Hakikat manusia menurut kitab suci Al-Qur'an adalah Basyar, Insan dan Nas (Hakim \& Mubarok, 2017).

Basyar menunjukkan bahwa pada manusia sebagai makhluk biologis yang berunsur materi seperti: makan, minum, seks, wisata, dan lain-lain. Insan yang menunjuk pada sifatsifat ruhani yang diberi ilmu, memikul amanah. Sebagai Insan, manusia ada yang taat dan ada yang membangkang agama. Nas mengacu pada manusia sebagai makhluk social. Secara keseluruhan Agama Islam memandang hakekat manusia sebagai makhluk yang 
sempurna dari segi asal-usul penciptaannya maupun tujuan penciptaannya (Petinova, 2018).

Dalam identifikasi Ibnul Jauzi manusia itu terdiri dari dua unsur yaitu jasad dan roh (Azmi \& Zulkifli, 2018). Aspek roh lebih penting karena esensi manusia adalah makhluk rohani sebagaimana hadis "Allah tidak memandang jasad dan bentuk manusia tapi Allah memandang hati dan amal manusia". Sebagai makhluk yang dianugerahi "roh", manusia tergolong makhluk religius.

Religius yang berasal dari kata religare menunjukkan pada agama. Religius berarti sikap religi tentang pengetahuan, keyakinan, pelaksanaan ibadah, serta penghayatan atas agama yang dianutnya dalam bentuk sosial dan aktivitas perwujudan beribadah. Sikap keagamaan ini diwujudkan dalam perilaku sehari-hari guna mencapai kebahagiaan dunia akhirat melalui perilaku ritual, sosial dan keyakinan kekuatan supranatural (Ancok \& Suroso, 2011).

Enam fungsi nyata pribadi religius dalam kehidupan manusia yaitu: edukatif, penyelamat, perdamaian, pengawasan sosial, fungsi pemupuk rasa solidaritas, dan fungsi transformatif (Abdullah, 2000). Agama memberikan ajaran-ajaran yang harus dipatuhi. Keselamatan yang diberikan oleh agama kepada penganutnya adalah keselamatan yang meliputi dua alam yaitu alam dunia dan akhirat. Melalui agama, seseorang yang bersalah atau berdosa dapat mencapai kedamaian batin melalui pemahaman agama. Ajaran agama oleh penganutnya dianggap sebagai norma, sehingga dalam hal ini agama dapat berfungsi sebagai pengawasan sosial secara individu maupun kelompok. Para penganut agama akan merasa memiliki kesamaan dalam kesatuan iman dan kepercayaan. Rasa kesatuan ini akan membina rasa solidaritas dalam kelompok maupun perorangan, bahkan kadang-kadang dapat membina rasa persaudaraan yang kokoh. Ajaran agama dapat mengubah kehidupan manusia seseorang atau kelompok menjadi kehidupan baru sesuai dengan ajaran agama yang dianutnya, kehidupan baru yang diterimanya berdasarkan ajaran agama yang dipeluk kadangkala mampu merubah kesetiannya kepada adat atau norma kehidupan yang dianutnya.

Dimensi Keyakinan (ideologis) berisi Pengharapan-pengharapan dimana orang yang religius berpegang teguh pada pandangan teologisnya. Dimensi praktik agama (ritualistik), mencakup pemujaan atau ibadah, ketaatan, dan komitmen terhadap agama yang dianutnya. Dimensi Pengalaman (eksperensial) seperti perasaan, persepsi, dan sensasi dalam suatu 
esensi ketuhanan. Dimensi Pengetahuan (intelektual), yakni mengetahui, memahami ajaran-ajaran agamanya. Dimensi Pengamalan (konsekuensial) berupa motivasi dalam kehidupan sosial, seperti suka menolong, dan adab bekerjasama.

Amir \& Lesmawati. (2017) mengatakan bahwa religiusitas memiliki pandangan teologi dari ajaran agama, yang mengarahkan mengikuti prinsip-prinsip yang berasal dari Tuhan. Religiusitas juga memiliki cara pengamalan ibadah yang diajarkan oleh institusi agama. Religiusitas dan spiritualitas membantu individu memahami berbagai persoalan dalam hidupnya.

Tulisan ini lebih menekankan pada kajian, bagaimana sesungguhnya karier dan religi, apakah kesatuan yang tidak terpisah, berbeda-beda atau tidak ada hubungan sama sekali? Pertanyaan ini berguna untuk membangun sikap karier secara religius, agar pemenuhan tuntutan mulia ajaran agama melandasi dalam pencapaian prestasi dalam kehidupan. Kepentingan puncak karier diposisikan secara tepat agar kebahagian sejati dalam maksud sesungguhnya.

\section{METODE}

Penelitian ini menggunakan metode kepustakaan (library research). Dalam teknisnya, metode ini berhadapan langsung dengan data teks, gambar, angka, kejadian dan benda lain. Oleh sebab itu, ia termasuk readymade yang mana peneliti tidak pergi ke mana-mana karna cukup menggunakan data yang tersedia di perpustakaan (Mestika, 2004)

Jenis penelitian termasuk kualitatif deskriptif pada literatur-literatur dan sumbersumber dan atau penemuan terbaru mengenai bimbingan konseling. Penelitian kepustakaan kadang bersifat kritis dan historis (Kaelan, 2010). Penelitian ini memiliki dimensi sejarah tentang karya tokoh pemikir keagamaan masa lalu. Penelitian kepustakaan ini bisa meliputi kritik pemikiran, penelitian naskah tertentu. Oleh karenanya, penelitian kepustakaan akan menghadapi sumber data berupa buku-buku.

Pengumpulan data dalam bentuk verbal simbolik berupa naskah-naskah yang belum dianalisis. Ada dua tahap dalam membaca data yang telah diperoleh: (1) membaca simbolik dengan menangkap sinopsis dari buku, bab, subbab sampai pada bagian terkecil dari buku. (2) membaca pada tingkat semantik, data yang telah dikumpulkan dengan lebih terperinci, terurai dan menangkap esensi dari data tersebut. 
Teknik yang digunakan dianalisis dengan model Miles dan Huberman. Dalam model ini aktifitas analisis kualitatif dilakukan secara interaktif dan terus-menerus sampai dirasa cukup. Berikutnya menganalisis kembali setelah data terkumpul yang berupa data mentah yang harus ditentukan hubungan satu sama lain (Moleong, 2017).

\section{HASIL DAN BAHASAN}

\section{Term Bimbingan Karier}

Bimbingan karier adalah suatu proses di mana peserta diberi perlakuan bimbingan untuk kehidupannya di masa yang akan datang. Bimbingan karier juga merupakan suatu cara untuk menumbuhkan keinginan seseorang untuk memiliki karier yang akan dipilih sendiri. Bimbingan karier merupakan metode yang mengacu pada pemahaman jenjang karier di masa depan. Dengan adanya bimbingan karier manusia dapat mengetahui apa rencana yang akan mereka capai untuk kesejahteraan mereka. Agar tujuan tersebut dapat tercapai maka setiap manusia harus dapat memahami apa konsepsi dan pengalaman selama bimbingan karier. Oleh sebab itu langkah selanjutnya agar proses dapat dengan mudah dicapai manusia harus melalui sutau rangkaian waktu, teknik, dan sistem bimbingan karier.

Adapun pengertian dari karier itu sendiri adalah proses suatu konsep yang tidak statis dan final. Banyak orang cenderung mendefinisikan karier sebagai "perjalanan karier seorang owner atau pegawai di dalam organisasi”. Perjalanan ini dimulai sejak ia memulai usaha atau diterima sebagai pegawai baru, dan berakhir pada saat ia berhenti berbisnis atau tidak bekerja lagi dalam organisasi tersebut.

Perjalanan karier seorang pegawai dimulai pada saat ia menerima pekerjaan di suatu organisasi. Perjalanan karier ini mungkin akan berlangsung beberapa jam saja atau beberapa hari, atau mungkin berlanjut sampai 30 atau 40 tahun kemudian. Perjalanan karier ini mungkin berlangsung di satu pekerjaan di satu lokasi, atau melibatkan serentetan pekerjaan yang tersebar di seluruh negeri atau bahkan di seluruh dunia.

Karier dapat diletakkan dalam konteks organisasi secara formal, tetapi karier dapat pula diletakkan dalam konteks yang lebih longgar dan tidak formal. Dalam kaitan arti yang terakhir ini, kita biasa mengatakan, misalnya, "karier si A sebagai guru cukup baik" dan si B mengakhiri kariernya di bidang garmen secara baik", dan sebagainya. 
Teknik pelaksanaan bimbingan dapat bermacam-macam, tergantung dari kebutuhan dan tujuannya. Artinya boleh minta bantuan orang lain yang ahli dalam bidangnya untuk memberikan bimbingan karier. Demikian juga metode dan peralatan yang dibutuhkan disesuaikan. Sistem evaluasi untuk bimbingan karier dapat dilaksanakan dalam berbagai cara, misalnya mengevaluasi apakah pelaksanaan bimbingan karier sudah sesuai dengan yang direncanakan, apakah tujuan sudah tercapai, apakah terjadi perubahan dalam dirinya, dan sebagainya.

Pekerjaan atau usaha merupakan salah satu aspek terpenting dalam kehidupan manusia, maka perlu direncanakan secara matang. Program bimbingan karier bertujuan untuk membantu orang dalam merencanakan karier di masa mendatang, agar karier yang dipilih sungguh sesuai dengan bakat, minat, dan nilai-nilai yang dijunjung tinggi. Jika orang memperoleh karier yang tepat, maka hidup orang akhirnya akan bahagia. Dan kebahagiaan adalah tujuan hidup semua orang. Oleh sebab itu bimbingan karier merupakan bagian yang tak terpisahkan dari tugas mewujudkan kebahagiaan itu.

\section{Konsep transisi karier}

Berkarier tidak identik dengan bekerja. Karier dalam suatu pekerjaan didorong oleh panggilan hidup yang disadari pikiran dan menjadi nila-nilai yang harus diwujudkan. Pendorong ini secara umum berupa sifat dari suatu pekerjaan. Misalnya berkarier sebagai pengusaha, agar terbebas dari ikatan waktu yang kaku, memiliki income yang bebas ditentukan sendiri, meningkatkan nilai tambah pada barang dan jasa sehingga mendapat keuntungan.

Widarto (2015) pekerjaan tidak dengan sendirinya merupakan karier. Terminologi bekerja sebagai istilah lain dari work, job, employment mengarah pada setiap aktivitas yang menghasilkan barang atau jasa, sedangkan terminologi karier (Inggris: career) lebih mengarah pada aktivitas pekerjaan atau jabatan yang dilandasi ketekunan keyakinan atas panggilan hidup, yang meresapi kesadaran pikiran dan perasaan seseorang, serta menggerakan seluruh gaya hidupnya. Oleh karena itu, karier lebih memerlukan persiapan dan perencanaan yang matang, bukan sekedar mendapat pekerjaan.

Pekerjaan dalam istilah occupation, vocation merupakan salah satu aspek terpenting dalam kehidupan manusia dewasa yang sehat, di mana pun dan kapan pun mereka berada. Orang akan merasa sangat susah dan gelisah jika tidak memiliki pekerjaan yang jelas. 
Berbagai penelitian menunjukkan bahwa komponen terpenting dari kehidupan manusia dewasa adalah keluarga dan pekerjaan. Dua komponen tersebut dijadikan penentu kebahagian hidup manusia, sehingga tidak mengherankan jika masalah pekerjaan dan keluarga sangat menyita seluruh perhatian, energi, dan waktu orang dewasa.

Pekerjaan memiliki peran yang sangat besar dalam memenuhi kebutuhan hidup manusia, terutama kebutuhan ekonomis dan psikologis. Secara ekonomis orang yang bekerja akan memperoleh penghasilan berupa uang yang bisa digunakan untuk membeli barang dan jasa guna mencukupi kebutuhan hidup sehari-hari. Secara psikologis orang yang memiliki pekerjaan akan lebih dihargai daripada orang yang menganggur, sehingga merasa lebih terhormat, meningkatkan harga diri dan kompetensi diri. Pekerjaan juga dapat menjadi wahana yang subur untuk mengaktualisasikan segala potensi yang dimiliki individu.

Ibarat pepatah, buah tidak akan jauh dari pohonnya. Boleh jadi arah kepada pilihan karier pun tidak jauh-jauh dari apa yang diamati dan menarik untuk ditiru dari keluarga dan lingkungan terdekat. Ketika belum sekolah, anak umur 4-5 tahun mengidentifikasi pekerjaan sebagaimana apa yang ada di dalam rumahnya. Anan belajar mengenakan pakaian, menggunakan alat dapur, menonton tv dan meniru-niru pekerjaan orangtuanya. Ketika anak masuk sekolah, mungkin kebanyakan dari mereka ingin menjadi guru dan menjadi polisi. Waktu sekolah awal ini tokoh terbaik dalam kariernya adalah guru berpakaian rapi nan ceria dan polisi gagah yang suka menolong. Ketika diberi tahu ada banyak karier selain guru dan polisi, seperti karier ulama, da'i, artis, pejabat negara, dokter, arsitek, insinyur, pengusaha industri, pedagang mall, pilot, wartawan, penyiar, atlet, dll.

Dorongan ke arah karier formal sepanjang tidak bertentangan dengan aturan agama dan negara diperbolehkan. Namun dalam masyarakat religius, dorongan kepada pilihan karier sepatutnya sebagai bagian dari keyakinan, pemahaman dan pengalaman agama. Karier menjadi dorongan religi untuk berkebaikan secara bijak antara pemenuhan aspek jasmani dan rohani.

\section{Faktor-Faktor yang Mempengaruhi Perlunya Bimbingan Karier}

Dunia pendidikan saat ini dihadapkan pada kendala yaitu banyaknya lulusan sekolah yang tidak mampu berkarya dalam usaha dan lapangan kerja pada umumnya. Kendala itu 
disebabkan oleh banyak hal, seperti persepi tentang entrepreneur yang negatif, jumlah lapangan kerja yang tidak sebanding dengan banyaknya jumlah lulusan tenaga kerja, kemampuan para pencari kerja yang kurang memadai, kekurangmampuan para pencari kerja dalam mencari pekerjaan, dan lain-lainnya. Sebagai langkah antisipasi untuk mempersiapkannya, maka diperlukan adanya bimbingan karier. Mereka membutuhkan bimbingan karier, khususnya dalam bantuan mengenai informasi tentang jenis pendidikan lanjut yang tepat, pemahaman kekuatan dan potensi untuk memasuki dunia karier, dan bimbingan untuk mengembangkan sikap dan keterampilan yang diperlukan untuk berkarier. Secara umum bimbingan karier dilaksanakan sebagai bagian dari program bimbingan konseling dalam institusi pendidikan. Bimbingan karier tersebut ditujukan untuk mempersiapkan diri sedemikian rupa agar memiliki standar kualitas yang sesuai dengan apa yang diperlukan dalam mencari pekerjaan, entrepreneur atau peran karier lainnya. Mereka diberi pengertian untuk memahami permasalahan yang terjadi di dunia kerja dan masyarakat bisnis. Dengan demikian, mereka sebagai calon pemangku karier sebagai tenaga kerja atau pelaku bisnis, atau jabatan tertentu sudah memiliki cukup persiapan untuk memasukinya.

\section{Proses Perkembangan Karier}

Pandangan tentang perkembangan karier berlingkup sangat luas. Perkembangan jabatan itu dipandang sebagai suatu proses yang mencakup banyak faktor. Dua faktor saling mempengaruhi, yakni sebagian terdapat pada individu sendiri dan untuk sebagian terdapat dalam lingkungan hidupnya. Keduanya berinteraksi satu sama lain dan bersamasama membentuk proses perkembangan karier seseorang. Pilihan karier merupakan suatu perpaduan dari aneka faktor pada individu sendiri seperti kebutuhan, sifat-sifat kepribadian, serta kemampuan intelektual. Adapun faktor di luar individu, seperti taraf kehidupan sosial-ekonomi keluarga, variasi tuntutan lingkungan kebudayaan, dan kesempatan yang muncul. Titik berat dari hal-hal tersebut tertumpu pada faktor-faktor individu itu sendiri.

Proses perkembangan karier dibagi atas lima tahap, yaitu: growth, explorasi, eshtablishment, maintenance, decline. Tahap pengembangan (growth) mulai dari saat lahir sampai umur lebih kurang 15 tahun. Anak mengembangkan berbagai potensi, pandangan khas, sikap, minat, dan kebutuhan- kebutuhan yang dipadukan dalam struktur gambaran 
diri (self-concept structure). Tahap eksplorasi (exploration) dari umur 15 sampai 24 tahun. Orang muda memikirkan berbagai alternatif jabatan, tetapi belum mengambil keputusan yang mengikat. Tahap pemantapan (establishment) dari umur 25 sampai 44 tahun. Bercirikan usaha tekun memantapkan diri melalui seluk-beluk pengalaman selama menjalani karier tertentu. Tahap pemeliharaan (maintenance) dari umur 45 tahun sampai 64 tahun.

Orang yang sudah dewasa menyesuaikan diri dalam penghayatan jabatannya. Tahap penurunan (decline). Orang memasuki masa pensiun dan harus menemukan pola hidup baru sesudah melepaskan jabatannya. Kelima tahap ini dipandang sebagai acuan bagi munculnya sikap-sikap dan perilaku yang menyangkut keterlibatan dalam suatu pekerjaan, yang tampak dalam tugas-tugas perkembangan karier (vocational developmental tasks).

Pada masa-masa tertentu dalam hidupnya individu dihadapkan pada tugas-tugas perkembangan karier tertentu, yaitu: (a) Perencanaan garis besar masa depan (crystalization) antara 14-18 tahun yang terutama bersifat kognitif dengan meninjau diri sendiri dan situasi hidupnya. (b) Penentuan (specification) antara umur 18-24 tahun yang bercirikan mengarahkan diri ke bidang jabatan tertentu dan mulai memegang jabatan itu. (c) Pemantapan (establishment) antara 24-35 tahun yang bercirikan membuktikan diri mampu memangku jabatan yang terpilih. (d) Pengakaran (consolidation) sesudah umur 35 tahun sampai masa pensiun yang bercirikan mencapai status tertentu dan memperoleh senioritas.

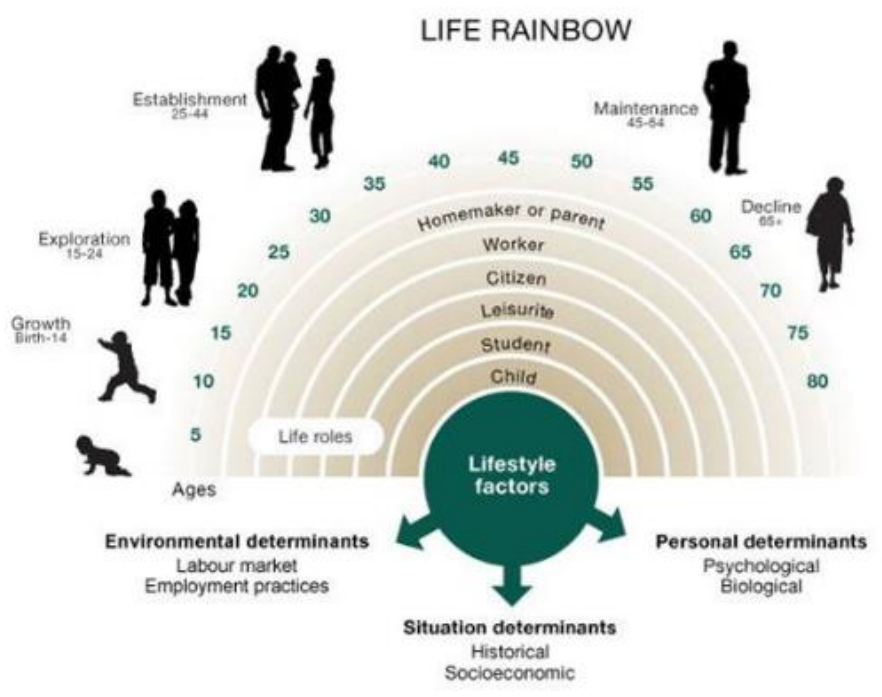

Gambar 1. Teori Karier Donald Super 
Berkaitan dengan tugas-tugas perkembangan karier, Donald Super mengembangkan konsep kematangan vokasional (career maturity/vocational maturity) yang menunjuk pada keberhasilan seseorang menyelesaikan semua tugas perkembangan vokasional yang khas bagi tahap perkembangan tertentu. Indikasi relevan bagi kematangan vokasional adalah misalnya kemampuan untuk membuat rencana, kerelaan untuk memikul tanggung jawab, serta kesadaran akan segala faktor internal dan eksternal yang harus dipertimbangkan dalam membuat pilihan jabatan atau memantapkan diri dalam suatu jabatan. Secara lebih rinci, fase pertumbuhan seseorang terkait dengan kariernya disajikan pada Tabel 1. Beraneka indikasi ini dapat dijabarkan lebih lanjut pada masing-masing tahap perkembangan vokasional, lebih-lebih selama masa remaja dan masa dewasa muda. Berkenaan dalam rangka meneliti dan menilai kematangan vokasional telah dikembangkan alat tes yang dikenal dengan nama Career Development Inventory, Career Maturity Test, dan Vocational Maturity Test.

\section{Faktor-Faktor yang Mempengaruhi Perlunya Bimbingan Karier}

Bimbingan karier merupakan hal yang sangat diperlukan bagi peserta untuk menghadapi dunia pekerjaan. Di mana persaingan sangat ketat, sehingga diperlukan kompetensi yang tinggi agar nantinya dapat bersaing. Pada awalnya, peserta harus melakukan beberapa langkah dalam mengembangkan dirinya, yaitu: (1) Mencapai perkembangan diri sebagai remaja yang beriman dan takwa kepada Tuhan Yang Maha Esa. (2) Mempersiapkan diri menerima dan bersikap positif serta dinamis terhadap perubahan fisik dan psikis yang terjadi pada diri sendiri untuk kehidupan yang sehat. (3) Mencapai pola hubungan yang baik dengan teman sebaya dalam perannya sebagai pria dan wanita. (4) Memantapkan nilai dan cara bertingkah laku yang dapat diterima dalam kehidupan yang lebih luas. (5) Mengenal kemampuan bakat, minta serta arah kecenderungan karier dan apresiasi seni. (6) Mengembangkan pengetahuan dan keterampilan untuk mengetahui serta mempersiapkan karier. (7) Mengenal gambaran dan mengembangkan sikap emosional, sosial dan ekonomi. (8) Mengenal sistem etika nilainilai bagi pedoman hidup sebagai pribadi, anggota masyarakat dan warga negara. 


\section{Tabel 1. Fase pertumbuhan karier}

\begin{tabular}{|c|c|c|}
\hline Tahap & Usia & Keterangan \\
\hline Pertumbuhan & $\begin{array}{l}\text { - Usia 4-10 (fantasi) } \\
\text { Identifikasi pekerjaan orang tua dan } \\
\text { keluarga. } \\
\text { - Usia 11-12 (peminatan) } \\
\text { Menunjukan minat, membedakan } \\
\text { pekerjaan seseorang di sekitarnya. } \\
\text { - Usia 13-14 (pengembangan kapasitas) }\end{array}$ & $\begin{array}{l}\text { Identifikasi pekerjaan orang tua dan keluarga. } \\
\text { Menunjukan minat, membedakan pekerjaan } \\
\text { seseorang di sekitarnya. } \\
\text { Sadar kapasitas diri, mencoba produktif, } \\
\text { mengatur waktu. }\end{array}$ \\
\hline Eksplorasi & $\begin{array}{l}- \text { Usia 15-17 (tentative) } \\
\text { - Usia 18-21 (transisi) } \\
\text { - Usia 22-24 (trial) }\end{array}$ & $\begin{array}{l}\text { Proses transisi komitmen pribadi, prevensi } \\
\text { tentative. } \\
\text { masih terbuka dan berganti-ganti, mencoba } \\
\text { mengeksplorasi. }\end{array}$ \\
\hline $\begin{array}{l}\text { Tahap } \\
\text { pemantapan }\end{array}$ & $\begin{array}{l}\text { - Usia 25-30 (penyesuaian) } \\
\text { • Usia 31-44 (kemajuan) }\end{array}$ & $\begin{array}{l}\text { Proses penyesuaian, ada pergeseran karier. } \\
\text { Seseorang meniti mobilitas karier, } \\
\text { berkembang pesat. }\end{array}$ \\
\hline $\begin{array}{l}\text { Tahap } \\
\text { pemeliharaan }\end{array}$ & 45-65 tahun (maintenance) & $\begin{array}{l}\text { puncak karier, pekerjaan "aman", pergeseran } \\
\text { dari individual ke sosial }\end{array}$ \\
\hline $\begin{array}{l}\text { Tahap } \\
\text { penurunan }\end{array}$ & $\begin{array}{l}\text { - Usia 65-70 tahun (deselarasi) } \\
\text { - Usia > } 70 \text { tahun (pensiun) }\end{array}$ & $\begin{array}{l}\text { susut, penurunan kemampuan } \\
\text { menarik diri, merenung makna hidup }\end{array}$ \\
\hline
\end{tabular}

Selain hal-hal di atas, para peserta juga harus memiliki pemahaman terhadap realita yang terjadi dalam dunia pekerjaan dan juga dalam kehidupan bermasyarakat. Hal-hal tersebut antara lain: (1) Kemajuan teknologi, (2) Pergeseran struktur ekonomi, (3) Pergeseran peran wanita, (4) Kekuatan dan kekurangan diri peserta, (5) Pengangguran. Kemajuan teknologi yang terjadi, membuat pola hidup masyarakat dan dunia pekerjaan mengalami perubahan yang terjadi secara besar-besaran. Dengan memanfaatkan teknologi baru yang dihasilkan, memungkinkan terjadinya peningkatan kinerja dan berbagai kegiatan dilakukan dengan cepat, tepat dan akurat sehingga akan meningkatkan produktivitas. Penggunaan teknologi baru dalam dunia kerja, antara lain Komputer dan perangkatnya. Diciptakannya mesin-mesin yang dapat berproduksi secara masal hingga tenaga kerja manusia tidak lagi mendominasi. Para peserta diharapkan memiliki keahlian dalam menggunakan atau memiliki pengetahuan dasar mengenai pengoperasian mesin tersebut. Diciptakannya robot untuk menggantikan peranan manusia. Robot sudah mulai diciptakan untuk meringankan pekerjaan manusia. Meskipun membuat robot merupakan teknologi yang sangat mahal dan sangat canggih sehingga sangat sedikit perusahaan yang mempergunakannya, namun tidaklah mustahil di masa mendatang robot diproduksi secara masal untuk mengantikan pekerjaan yang dilakukan manusia. Para peserta sebaiknya membekali dirinya agar memiliki keahlian tersendiri dalam bekerja. 
Dengan terjadinya pergeseran struktur ekonomi tidak semestinya keadaan pendidikan menjadi terganggu, yang berdampak besar pada perkembangan karier seseorang tersebut. Adanya dampak yang terjadi dari pergeseran struktur ekonomi, antara lain adalah sebagai berikut:

Ketidakcocokan yang bersifat geografis, jenis pekerjaan, orientasi status atau masalah keahlian khusus. Hasil studi yang menemukan gejala meningkatnya pengangguran terdidik di Indonesia antara lain disebabkan adanya keinginan memilih pekerjaan yang aman dari risiko. Dengan demikian angkatan kerja terdidik lebih suka memilih menganggur daripada mendapat pekerjaan yang tidak sesuai dengan keinginan mereka. Belum efisiennya fungsi pasar tenaga kerja, menyebabkan banyak angkatan kerja bekerja di luar bidangnya. Hal ini tentu saja berpengaruh pada efektivitas dan efisiensi penggunaan tenaga kerja.

Saat ini peran wanita telah bergeser dari peran tradisional menjadi modern. Peran wanita dalam kehidupan tradisional adalah untuk mengurus anak dan rumah tangga, kini wanita memiliki peran sosial dimana wanita dapat berkarier dalam berbagai bidang, seperti bidang industri, ekonomi, bidang sosial, bidang politik, dan lain-lainnya. Pergeseran peran ini bukanlah hal yang mudah. Secara tradisional, peran wanita seolah dibatasi dan ditempatkan pada posisi pasif. Wanita hanyalah pendukung karier suami. Peran wanita yang terbatas pada peran reproduksi dan mengurus rumah tangga membuat wanita identik dengan pengabdian kepada suami dan anak. Sementara wanita modern dituntut untuk berpendidikan tinggi, berperan aktif, dan kritis. Sebagai wanita karier, tuntutan sebagai ibu rumah tangga pun tidak terhindarkan. Seoarang wanita harus dapat berperan ganda, yaitu sebagai ibu rumah tangga yang baik, dan juga dituntut untuk dapat mengembangkan kariernya. Untuk itu wanita harus senangtiasa bugar, produktif, dan memiliki keseimbangan jiwa. Analisis peran wanita merupakan salah satu langkah awal ke arah peningkatan partisipasi wanita dalam peningkatan dan pengembangan karier. Konsepsi dasar dari upaya ini adalah mengangkat hakekat, kodrat serta peranan wanita sebagai salah satu bagian integral dari peranan wanita dalam konteks pembangunan. Oleh karena itu, berdasarkan hal tersebut diperlukan kajian awal yang bertujuah untuk: (1) memperoleh gambaran obyektif dan komprehensif mengenai, situasi dan peranan wanita sekarang ini; (2) memperoleh gambaran yang obyektif tentang kendala-kendala yang masih menjadi penghambat bagi kemajuan wanita; (3) memperoleh gambaran tentang 
kebijakan-kebijakan pemerintah yang sudah berhasil maupun belum berhasil dalam; upaya meningkatkan peranan wanita di daerah ini; serta (4) dapat memberikan analisis situasi wanita pada masa yang akan datang dengan menggunakan situasi lampau dan sekarang sebagai tolok ukurnya.

Banyaknya tindakan yang mencerminkan bahwa peserta itu kurang mampu, misalnya dengan banyaknya peserta yang melakukan pelanggaran selama studi yang diberikan oleh pendidik. Menyangkut bimbingan karier, peserta yang merasa dirinya kurang mampu dalam pendidikan atau pun ketidaksiapan diri dengan keadaan di sekitar dirinya baik perubahan sistem ekonomi, kemajuan teknologi, dan lain-lain. Ginzberg (1972) menegaskan bahwa proses pilihan karier itu terjadi sepanjang hidup manusia, artinya bahwa suatu ketika dimungkinkan orang berubah pikiran. Hal ini berarti bahwa pilihan karier tidaklah terjadi sekali saja dalam hidup manusia. Di samping itu Ginzberg juga menyadari bahwa faktor peluang/kesempatan memegang peranan yang amat penting. Meskipun seorang remaja sudah menentukan pilihan kariernya berdasar minat, bakat, dan nilai yang ia yakini.

Banyaknya terjadi pengangguran akibat banyak dari masyarakat tidak mampu mengikuti perubahan dari jaman, berarti orang tesebut ketika di sekolah atau di kuliah sering bermain-main, sehingga ketika lulus dari sekolah atau kuliah peserta tidak mempunyai bekal yang cukup untuk mauk kedunia kerja. Banyaknya pengangguran akibat dari majunya perkembangan teknologi, yang mana perkembangan teknologi itu mempunyai dampak positif dan dampak negatifnya, contoh dampak negatifnya yaitu: banyaknya dunia industri yang menggunakan robot, sehingga posisi pekerjaan manusia digantikan oleh robot. Dan dampak positifnya manusia tidak kesusahan karena pekerjaannya dibantu oleh robot, pengeluaran produksi bisa lebih ditekan, dan tingkat kesalahan yang dilakukan oleh robotik semakin sedikit, dan perusahan itu mendapatkan keuntungan yang besar. Pengangguran terjadi karena peserta tidak mengalami kesiapan mental untuk mengikuti perkembangan jaman, dengan pergeseran struktur ekonomi, pergeseran peran wanita, dan kemajuan teknologi, dengan peserta diberikan bimbingan karier peserta akan mengalami proses pembekalan karier, yang mana pembekalan itu akan berefek besar di masa depan. 


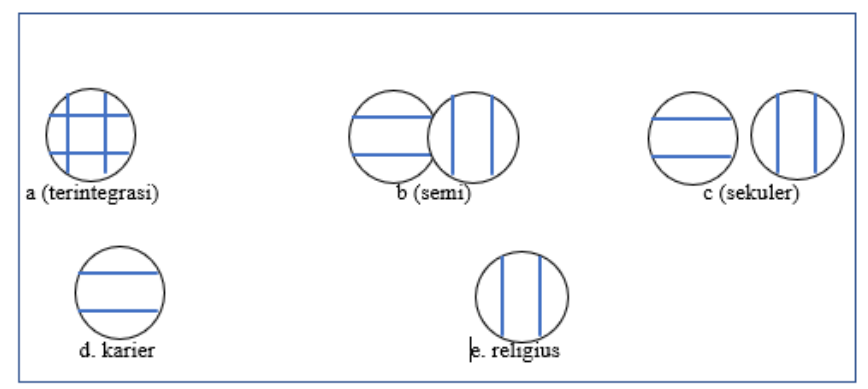

\section{Gambar 2. Hubungan manusia religius dengan karier}

\section{Hubungan karier dengan religi}

Karier dan religi semestinya merupakan bagian yang tak terpisahkan. Namun manusia memerlukan waktu untuk menerima agama sebagai kesleuruhan dalam hidup. Wahib (2015) menyatakan bahwa kriteria orang yang mampu menerapkan lima aspek religiusitas: kemampuan melakukan differensiasi, dinamis, integral, berimbang antara kesenangan dunia tanpa melupakan akhirat. Kemampuan melakukan differensiasi bersikap dan berperilaku terhadap agama secara obyektif, kritis, berfikir secara terbuka. Berkarakter dinamis mampu mengontrol dan mengarahkan motif- motif dan aktivitas demi kepentingan agama itu sendiri. Integral, menyatukan sisi religiusitas dengan segenap aspek kehidupan termasuk sosial, ekonomi. Sikap Berimbang Antara Kesenangan Dunia Tanpa Melupakan Akhirat, mampu menempatkan diri antara batas kecukupan dan batas kelebihan.

Hubungan Pekerjaan manusia dengan agama pada awalnya mungkin berlainan (sekuler) berbeda antara pandangan agama dan pekerjaan. Misalnya wanita dalam shalat menggunakan kerudung namun dalam pebekerjaan tidak menggunakan tutup kepala. Kemudian seiring perjalanan hidup seseorang, agama dan karier mulai saling mendekat, ini termasuk pada kriteria semi. Pada tahap selanjutnya agama dan karier menjadi kesatuan yang terintegrasi (kaffah), kongruen (sama dan sebangun). Kongruensi ini yang diharapkan dalam kehidupan umat beragama.

\section{KESIMPULAN}

Masa adolesen adalah masa perkembangan individu yang krusial. Masa dimana individu mencari identitas dalam dirinya. Dirinya, keluarga dan orang lain disekitarnya mempunyai hubungan yang sangat erat karena mempunyai pengaruh dalam setiap individu kedepannya. Sehingga pondasi yang penting dalam setiap fase kehidupan termasuk dimasa adolesen adalah pondasi pendidikan spiritual dari sejak dini. Seperti 
yang dikatakan John locke bahwa lingkungan akan mempunyai pengaruh yang besar terhadap perkembangan individu. Pondasi spiritual membentengi individu dalam kehidupan sehari-hari dalam tatanan yang baik dan positif.

\section{DAFTAR RUJUKAN}

Abdullah, A. (2000). Mencari Islam: Studi Islam dengan Berbagai Pendekatan. Yogyakarta: Tiarawacana.

Afrida. (2018). Hakikat Manusia dalam perspektif Al-Quran. Al-Qisthu: Jurnal Ilmu-Ilmu Hukum, 16(2), 54-59.

Amir, Y., \& Lesmawati, D. R. (2017). Religiusitas Dan Spiritualitas: Konsep Yang Sama Atau Berbeda?. Jurnal Ilmiah Penelitian Psikologi: Kajian Empiris \& NonEmpiris, 2(2), 67-73. https://doi.org/10.22236/JIPP-21.

Ancok, D. \& Suroso, F. N. (2011). Psikologi Islam Solusi Islam Atas Problem-Problem Psikologi. Yogyakarta: Pustaka Pelajar.

Azmi, M. N., \& Zulkifli, M. (2018). Manusia, Akal Dan Kebahagiaan (Studi Analisis Komparatif antara Al-Qur'an dengan Filsafat Islam). Al Qalam: Jurnal Ilmiah Keagamaan dan Kemasyarakatan, 12(2), 123-143.

Ginzberg, E. (1972). Toward a Theory of Occupational Choice: A Restatement. Vocational Guidance Quarterly, 20(3), 2-9. https://doi.org/10.1002/j.2164585x.1972.tb02037.x.

Hakim, A. A., \& Mubarok, J. (2017). Metodologi Studi Islam. Bandung: Rosda.

Kaelan. (2010). Metode Penelitian Agama Kualitatif Interdisipliner. Yogyakarta: Paradigma.

Maryam, S. (2017). Studi Komparasi Emik Dan Etik Masyarakat Terhadap Menjamurnya Tayangan Drama Asing Di Indonesia: Kajian Antropologi Kontemporer. GENTA BAHTERA: Jurnal Ilmiah Kebahasaan dan Kesastraan, 3(1), 91-105.

Mestika, Z. (2004). Metode Penelitian Kepustakaan. Jakarta: Yayasan Obor Indonesia. Moleong, L. J. (2017). Metodologi Penelitian Kualitatif. Bandung: Remaja Rosdakarya.

Petinova, O. (2018). "Homo Economicus" Through the Lens of Metaphysics of Economics. Philosophy and Cosmology, 21(21), 84-93.

Widarto. (2015). Bimbingan Karir dan Tips Berkarir. Yogyakarta: Leutikaprio.

Wahib, A. (2015). Psikologi Agama Pengantar Memahami Perilaku Agama. Semarang: Karya Abadi Jaya. 